\title{
Folylpolyglutamate Synthase, Mitochondrial
}

National Cancer Institute

\section{Source}

National Cancer Institute. Folylpolyg lutamate Synthase, Mitochondrial. NCI Thesaurus.

Code C103942.

Folylpolyg lutamate synthase, mitochondrial (587 aa, $\sim 65 \mathrm{kDa}$ ) is encoded by the human FPGS gene. This protein plays a role in the conversion of folates to polyg lutamate derivatives. 